\section{AL-AZHAR}

Assiut Dental Journal
The Official Publication of The

Faculty of Dental medicine.

Al-Azhar Assiut Uniuersity.

AADJ, Vol. 3, No. 1, April (2020) - PP. 83:88

ISSn 2682-2822

\title{
Efficacy of Tranexamic Acid on The Incidence of Dry Socket Following Lower Third Molar Surgery
}

\author{
Mohamed E. Mohamed ${ }^{1}$, Mahmoud A. Abdallah ${ }^{1}$, Abdel Aziz B. Abdullah ${ }^{2 *}$
}

Codex : 10/2020/04

Aadj@azhar.edu.eg

\section{KEYWORDS}

Dry Socket,

Tranexamic Acid,

Gelfoam,

Third Molar Extraction,

Trismus.

1. Department of Oral and Maxillofacial Surgery, Faculty of Dental Medicine (Boys), Cairo, Al-Azhar University, Egypt.

2. Department of Oral and Maxillofacial Surgery, Faculty of Dental medicine, Assiut, Al-Azhar University, Egypt.

* Corresponding Author e-mail: abdelazizbaiomy@azhar.edu.eg

\begin{abstract}
Aim: This study aims to evaluate the efficacy of tranexamic acid on the incidence of DS following lower third molar surgery. Subjects and methods: Twenty patients with symptomatic impacted mandibular third molar were extracted. Patients were randomly allocated into two groups. In group A; gelfoam soaked in 5\% tranexamic acid solution was placed in the socket after extraction. In group B, gelfoam soaked in saline was placed in the socket. Pain, bleeding, edema and trismus were evaluated on the $2^{\text {nd }}$, $4^{\text {th, }} 7^{\text {th }}$ and $14^{\text {th }}$ postoperative days. Results: Results have indicated that the incidence of DS was $20 \%$ in group B in whereas in group A it was $0 \%$. Postoperative pain was significantly lesser in group A than group B at the day of surgery, $2^{\text {nd }}$ and $4^{\text {th }}$ postoperative days. At the $7^{\text {th }}$ and $14^{\text {th }}$ days the difference was nonsignificant. TXA has no effect on the mouth opening and postoperative swelling following lower third molar surgery. Conclusion: Intra socket application of TXA after mandibular third molars surgery may help reduce the incidence of DS.TXA is more effective than gelfoam for prevention of DS. Intra socket application of TXA decreased the intensity of pain especially in the early postoperative days.
\end{abstract}

\section{INTRODUCTION}

Dry socket is the most common complication following tooth extraction having peak incidence in the $18-45$ years old age group. The incidence of dry socket varied between $1-4 \%$ for all routine dental extractions and $5-30 \%$ for impacted mandibular third molar. ${ }^{1,2}$ The exact etiology of dry socket is not well understood. It is believed that it is an increased local fibrinolysis leading to disintegration of the clot. ${ }^{3}$ During the last decades attempts have been made to find the proper way for prevention of dry socket. These included the use of antibiotic, chlorhexidine rinse, gelfoam and topical antifibrinolytic agent. ${ }^{4-7}$ Some forms of treatment methods of dry socket have been proposed like antibiotic, suturing, alveogel and eugenol, low level laser and plasma rich in growth hormone..$^{8-11}$ 
Tranexamic acid is a simple, inexpensive, antifibrinolytic agent impedes the proteolytic degradation of fibrin by preventing the attachment of plasminogen and plasmin. ${ }^{12} \mathrm{~A} 4.8 \%$ solution has been proven to be very effective in reducing bleeding complications with negligible systemic absorption and might prevent dry socket when applied topically in the extraction socket following dental extraction. ${ }^{13,14}$

\section{PATIENTS AND METHODS}

This randomized clinical study was carried out at outpatient clinic of Oral and Maxillofacial Surgery Department, Faculty of Dental Medicine,Boys, Cairo, Al-Azhar University. After approval of ethical review committee, the informed consent was taken from all patients. The study included 20 patients underwent surgical extractions of mandibular third molar. The inclusion criteria was patients with impacted mesioangular mandibular third molar ,male or female patients,young patients in the $3^{\text {rd }}$ decade of life, the site of surgery should be free of infection and inflammation, no history of recent medications intake like antibiotics or analgesics. The exclusion criteria was patients with history of bleeding tendency, hypersensitive patients to the proposed medications including anesthesia, immuno-compromised patients, patients with history of radiotherapy or chemotherapy,bad oral hygiene. Patients were randomly allocated into two groups per 10 patients each. In group A; a gelfoam soaked in 5\% TXA solution was placed in the socket after tooth delivery. In group B, a gelfoam soaked in saline solution was placed in the socket after tooth delivery. Inferior alveolar, lingual, and long buccal nerves were anesthetically blocked. A full-thickness mucoperiosteal flap elevated, the overlying bone was removed for exposure of the tooth, and the exposed tooth sectioned and removed. Following tooth removal, in group A, a gelfoam soaked in tranexamic acid was placed in the socket followed by suturing. In group B, a gelfoam soaked in saline was placed in the socket followed by suturing. Patients instructed to avoid rinsing for the coming 24 hours after surgery. Oral hygiene maintenance measures were emphasized. Sutures removed on the $7^{\text {th }}$ postoperative day. Patients were called for check up on the $2^{\text {nd }}, 4^{\text {th, }} 7^{\text {th }}$ and $14^{\text {th }}$ day to look for dry socket by any increased severity of pain and loss of the blood clot. Other postoperative sequelae were recorded as bleeding, infection, edema, and trismus.

\section{Assessment of maximal mouth opening:}

Maximal mouth opening was measured immediately before surgery as the distance between the cutting edges of the right maxillary and right mandibular central incisors using vernier scale. This was considered as the preoperative base line measurement of the maximal mouth opening (fig 1).

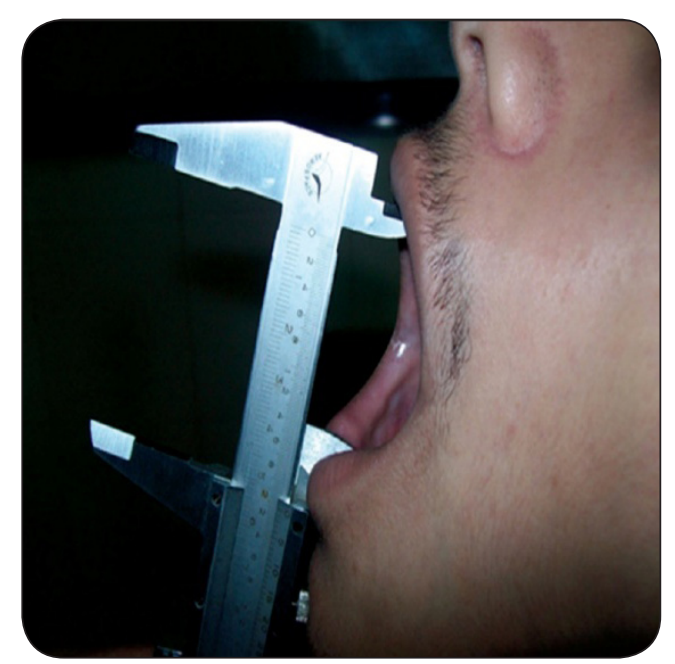

Fig. (1) Use of vernierscale for measurement of MMO

\section{Cheek dimensions:}

Cheek dimensions were measured in millimeters with a flexible measuring tape using the following 3 reference planes (fig 2).

1. AC- the most posterior point on the tragus to the lateral point on the corner of mouth.

2. AD- the most posterior point on the tragus to the soft tissue pogonion.

3. BE- the lateral canthus of the eye to the most inferior point on the angle of the mandible. 
The sum of $\mathrm{AC}+\mathrm{AD}+\mathrm{BE}$ was considered as the preoperative base line cheek dimension value. These measurements were taken immediately before surgery on the patients operated side.

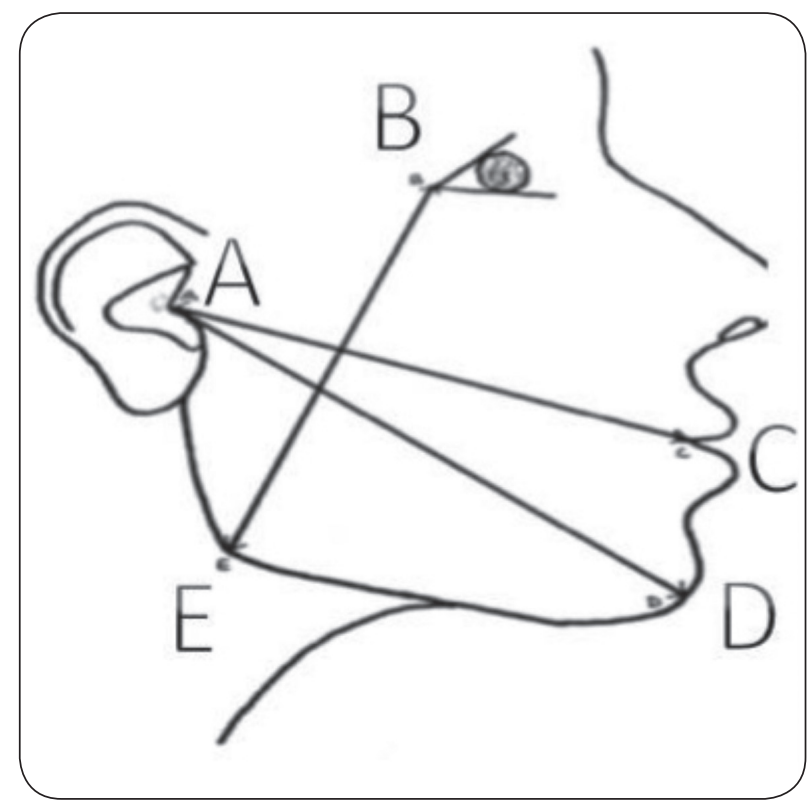

Fig. (2) AC, AD and BE lines used for measurement of cheek dimension

Data were tabulated, coded then analyzed using the program SPSS version 23.

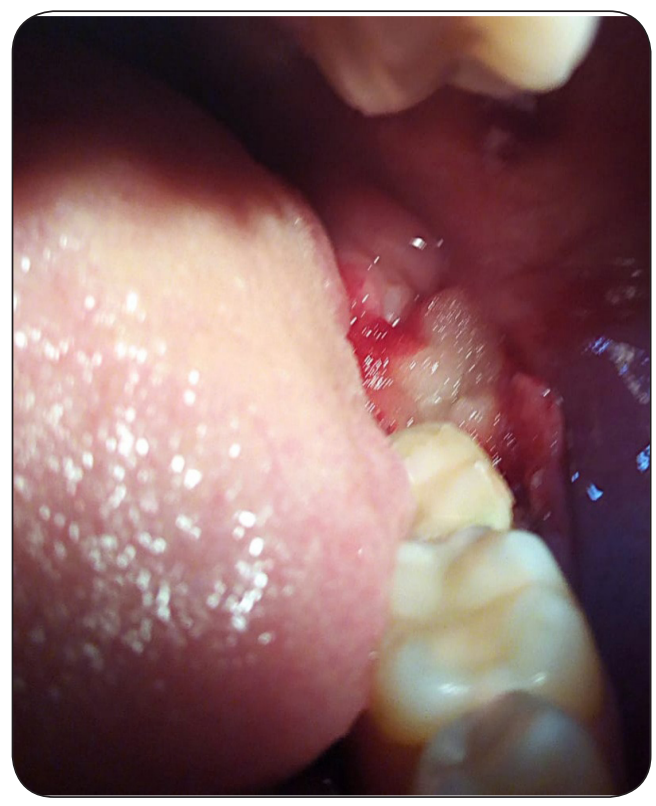

Fig. (3) Gelfoam soaked in TXA inside the socket

\section{RESULTS}

Of the total number of patients, $60 \%$ were male and $40 \%$ female. There was no significant difference in the frequency of gender in the groups. The mean age of the patients was $29.30 \pm 3.47$ in group A and $29.40 \pm 3.63$ in group B. There was no significant difference. The mean values of the duration of surgery were $25.90 \pm 4.20$ and $25.60 \pm 4.12$ in groups $\mathrm{A}$, and $\mathrm{B}$ respectively. There was no significant difference. Incidence of dry socket was $20 \%$ in Group B whereas in group A it was $0 \%$ with p-value 0.47 . No significance difference was found between the two groups on bleeding scale. Postoperative pain intensity was significantly lesser in group A than group B at the day of surgery, $2^{\text {nd }}$ and $4^{\text {th }}$ postoperative days. At the $7^{\text {th }}$ and $14^{\text {th }}$ days the difference was nonsignificant. The analgesic consumption was higher in group B than in group A. The difference between groups was statistically significant. The difference between both groups was statistically nonsignificant on the postoperative swelling and maximal mouth opening.

Table (1): Comparison between both groups

\begin{tabular}{|c|c|c|c|c|}
\hline \multirow{2}{*}{\multicolumn{2}{|c|}{ Age }} & Group A & Group B & $\mathrm{p}$ \\
\hline & & 29.3 & 29.4 & 0.95 \\
\hline \multirow[t]{2}{*}{ Gender } & Female & $50 \%$ & $30 \%$ & \multirow{2}{*}{0.65} \\
\hline & Male & $50 \%$ & $70 \%$ & \\
\hline \multicolumn{2}{|c|}{ Duration of surgery } & 25.9 & 25.6 & 0.87 \\
\hline \multicolumn{2}{|c|}{ Dry socket $\%$} & $0 \%$ & $20 \%$ & 0.47 \\
\hline \multicolumn{2}{|c|}{ Bleeding } & 0 & 0 & 0.28 \\
\hline \multirow{5}{*}{ Pain } & Day of surgery & 7.00 & 8.00 & $.02 *$ \\
\hline & 2 day & 4.50 & 5.50 & $.028 *$ \\
\hline & 4 day & 3.00 & 4.00 & $.024 *$ \\
\hline & 7 day & 0.50 & 2.00 & $.058^{*}$ \\
\hline & 14 day & 0.00 & 0.00 & $.147 *$ \\
\hline \multirow{5}{*}{$\begin{array}{c}\text { Analgesic } \\
\text { consumption }\end{array}$} & day of surgery & 2 & 3.00 & $.003 *$ \\
\hline & 2 day & 1 & 2.00 & $.029 *$ \\
\hline & 4 day & 1 & 2.00 & $.035^{*}$ \\
\hline & 7 day & 0 & 0.00 & 0.79 \\
\hline & 14 day & 0 & 0.00 & 1.00 \\
\hline
\end{tabular}




\begin{tabular}{|c|c|c|c|c|}
\hline \multirow{4}{*}{$\begin{array}{c}\text { Cheek } \\
\text { dimension }\end{array}$} & Pre & 371.8 & 374.60 & 0.38 \\
\cline { 2 - 5 } & 2 day & 375.8 & 379.80 & 0.26 \\
\cline { 2 - 5 } & 4 day & 359.3 & 354.20 & 0.14 \\
\cline { 2 - 5 } & 7 day & 364.4 & 362.90 & 0.67 \\
\hline \multirow{4}{*}{$\begin{array}{c}\text { Mouth open- } \\
\text { ing }\end{array}$} & 14 day & 359 & 354.00 & 0.15 \\
\cline { 2 - 5 } & Pre & 4.42 & 4.39 & 0.84 \\
\cline { 2 - 5 } & 2 day & 3.3 & 3.26 & 0.8 \\
\cline { 2 - 5 } & 4 day & 3.53 & 3.49 & 0.8 \\
\cline { 2 - 5 } & 7 day & 3.82 & 3.82 & 1 \\
\hline \multirow{2}{*}{} & 14 day & 4.22 & 4.15 & 0.63 \\
\hline
\end{tabular}

\section{DISCUSSION}

Dry socket is a common postoperative problem that is especially prevalent after the removal of mandibular third molars. The high prevalence (5\% to $30 \%$ ) of dry socket and its associated discomfort and complications remain one of the most important concerns of the oral and maxillofacial surgery profession. Although the etiology of dry socket is not clear, fibrinolysis with subsequent loss of blood clotting is believed to be the general cause of dry socket. Many clinical investigations and researchers have sought to prevent or reduce the incidence of dry socket. The treatment is merely symptomatic and is limited to pain alleviation. Tranexamic acid, an antifibrinolytic agent, has been speculated to prevent dry socket when applied topically in the extraction socket ${ }^{15}$. It exerts its antifibrinolytic effect by blocking lysine binding sites on plasminogen molecules. It inhibits the interaction of plasminogen and the heavy chain of plasmin with lysine residues on the surface of fibrin. ${ }^{16}$ The shorter surgical procedures time the less postoperative complication. The duration of surgery was short in both groups. This is in agreement with Pavan et $a{ }^{17}$ who concluded that extended operation time has an impact over postoperative complications. Dry socket may affect female in ratio of 5:1 with respect to males. ${ }^{18}$ According to Sweet \& Buttler ${ }^{19}$, the incidence of dry socket was $4 \%$ in female while $0.5 \%$ in males. Naqash et $\mathrm{al}^{15}$ reported that it was $31.25 \%$ in males whereas in females it was found to be $30.77 \%$. In the current study, no sex predilection in the distribution of dry socket was found. The incidence of dry socket has been reported between $1 \%$ and $45 \%$ for various teeth in the literature with an incidence that can reach up to $38 \%$ on extraction of mandibular molars. ${ }^{18}$ The overall incidence of dry socket recorded in the present study is $10 \%$. The incidence of dry socket in group B was $20 \%$ and $0 \%$ in group A. Result of the present study is in accordance with the results of Anand et $\mathrm{al}^{14}$ who found that the incidence of dry socket was $6.66 \%$ among the patients administered TXA both orally and systematically and 30\% among those who received no such treatment. In another study, Naqash et a ${ }^{15}$ found that the use of TXA applied locally with soaked pressure gauze following the removal of the teeth reduces the incidence of AO. On the other hand, Svensson et $\mathrm{al}^{20}$ found no cases of dry socket with the use of TXA after extraction. It has been proclaimed that dry socket starts 1-3 days after extraction of tooth ${ }^{2}$. This is exactly what happened in this study as one case of dry socket appeared on the $1^{\text {st }}$ postoperative day and the other case appeared on the $2^{\text {st }}$ postoperative day. Finding of the current study agreed along with Nitzan ${ }^{21}$ who stated that dry socket cannot take place in the same operative day, as the blood clot, itself, contain antiplasmin that must be consumed by plasmin before clot lysis could occur, a process that takes at least 24 hours. The post operative pain assessment was reduced on TXA group on all follow up days. The pain reduction by TXA was significant on the day of surgery, $2^{\text {nd }}$ and $4^{\text {th }}$ postoperative days and non significant on the $7^{\text {th }}$ and $14^{\text {th }}$ postoperative days. This may be due to the positive effect that TXA can play in reduction of dry socket formation in group A.

\section{CONCLUSIONS}

Based on the results of this study it could be concluded that: 
- Intra socket application of TXA after mandibular third molars surgery may help reduce the incidence of dry socket.

- TXA is more effective than gelfoam for prevention of dry socket.

- Intra socket application of TXA decreased the intensity of pain especially in the early postoperative days.

- TXA has no effect on the postoperative trismus and swelling.

\section{REFERENCES}

1. Blum I. Contemporary views of dry socket $(\mathrm{AO})$ : a clinical appraisal of standardization, aetiopathogenesis and management: a clinical review. Int J Oral Maxillofac Surg. 2002; 31:309-17.

2. Noroozi A, Philbert R. Modern concepts in understanding and management of the "dry socket" syndrome: comprehensive review of the literature. Oral Surg Oral Med Oral Pathol Oral Radiol Endod 2009; 107:30-5.

3. Cardoso C, Rodrigues M, Ferreira J, Garlet G, de Carvalho P. Clinical concepts of dry socket. J Oral Maxillofac Surg 2010; 68:1922-32.

4. Ishihama K, Kimura T, Yasui Y, Komaki M, Ota Y. Azithromycin as prophylaxis for the prevention of postoperative infection in impacted mandibular third molar surgery. J infect chemother. 2006; 12:31-5.

5. Minguez-Serra M, Salort-Llorca C, Silvestre-Donat F. Chlorhexidine in the prevention of dry socket: effectiveness of different dosage forms and regimens. Med Oral Pathol Oral Cir Bucal. 2009; 14:e445-9.

6. Wang Y, Guan Q, Li Y, Guo J, Jiang L, Jia M, et al. Use of "gelatamp" colloidal silver gelatin sponge to prevent dry socket after extracting mandibular impacted teeth. Shanghai Kou Qiang Yi Xue. 2013; 22:108-10.

7. Kolokythas A, Olech E, Miloro M. Alveolar osteitis: a comprehensive review of concepts and controversies. Int J Dent.2010;2010:1-10.

8. Bezerra T, Studart-Soares E, Scaparo H, Pita-Neto I, Batista S, Fonteles C,et al. Prophylaxis versus placebo treatment for infective and inflammatory complications of surgical third molar removal: a split-mouth, double-blind, controlled, clinical trial with amoxicillin (500 mg) J Oral
Maxillofac Surg. 2011;69:e333-9.

9. Osunde O, Adebola R, Saheeb B. A comparative study of the effect of suture-less and multiple suture techniques on inflammatory complications following third molar surgery. Int J Oral Maxillofac Surg. 2012; 41:1275-9.

10. Kaya G, Yapici G, Savas Z, Gungormus M. Comparison of alvogyl, SaliCept patch, and low-level laser therapy in themanagement of alveolar osteitis. J Oral Maxillofac Surg 2011;69:1571-7.

11. Haraji A, Lassemi E, Hosein M, Motamedi K, Alavi M, Adibnejad S,et al. Effect of plasma rich in growth factors on alveolar osteitis. Natl J Maxillofac Surg. 2012; 3:38-41.

12. Ker K, Edwards P, Perel P, Shakur H, Roberts I. Effect of tranexamic acid on surgical bleeding. Br Med J. 2012;344: e3054-15.

13. Patatanian E, Fugate S. Hemostatic mouthwashes in anticoagulated patients undergoing dental extraction.Ann Pharmacother. 2006;40:2205-10.

14. Anand K, Patro S, Mohapatra A, Mishra S.The efficacy of tranexamic acid in the reduction of incidence of dry socket. J Clin Diagn Res. 2015; 9: 25-8.

15. Naqash M, Gulraiz Z, Fatima T, Tooba A, Fahad A, Syed S. Efficacy of Topical Tranexamic Acid Application for Dry Socket Prevention. IJABR. 2019 ;10 :751-7.

16. Perel P, Ker K, Morales U, Roberts I. Tranexamic acid for reducingmortality in emergency and urgent surgery. Cochrane Database Syst Rev. 2013;1: CD010245.

17. Pavan T, Ashwini M, Anand M, Syed F, Santosh M, Kundan S. An Assessment of Factors Influencing the Difficulty in Third Molar Surgery.Ann Maxillofac Surg. 2017; 7: 45-50.

18. Karnure M, Neha M.Review on conventional and novel techniques for treatment of alveolar osteitis. Asian J Pharm Clin Res. 2013; 6 :13-7.

19. Sweet J, Butler D. Predisposing and operative factors: effect on the incidence of localized osteitis in mandibular third molar surgery. Oral Surg Oral Med Oral Pathol. 1978;46:206-15.

20. Svensson R, Fredrik H, Charlotta S, Peter J., Jonas P. Treatment with local hemostatic agents and primary closure after tooth extraction in warfarin treated patients.swed dent j. 2013; 37: 71-7.

21. Nitzan D. On the genesis of "dry socket". J Oral MaxillofacSurg. 1983; 41: 706-10. 


\author{
مجلة أسيوط لطب الأسنان
}

النشر الرسمي لكلية طب الأسنان جامعة الأزهر أسيوط لكاطية

\section{فعالية حمض الترانيكساميك على نسبة حدوث الحمة الحماث الحق الجاف بعد جراحة ضرس العقل السفلم السفاك}

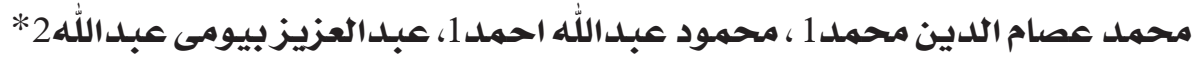

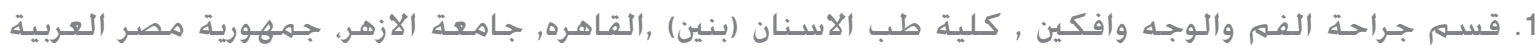

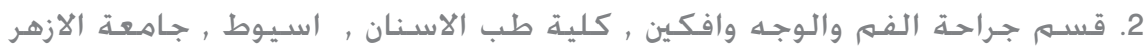

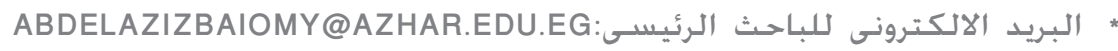

الملخص:

الهـدف: تهدف هذه الدراسـة إلى تقييم فعالية حمض الترانيكسـاميك على نسبة حدوث الحق الجاف بعد جراحة ضرس العقل السـفلى.

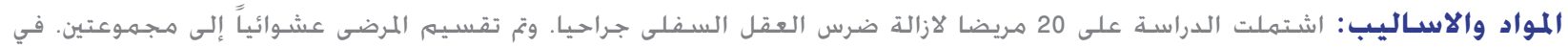

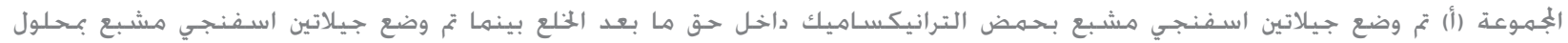

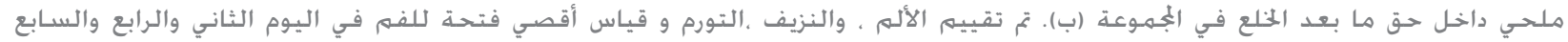

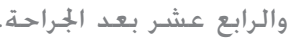

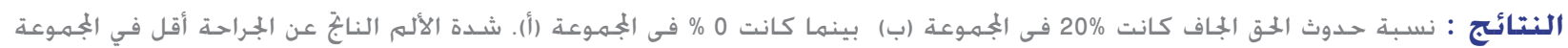

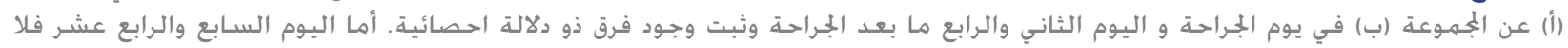

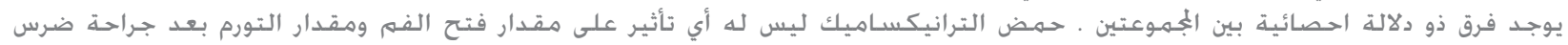

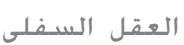

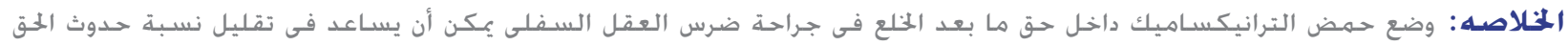

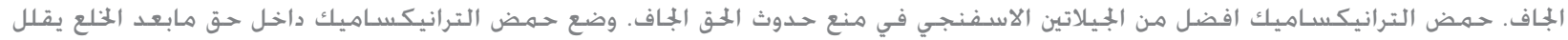

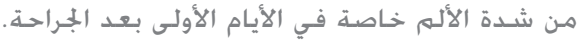

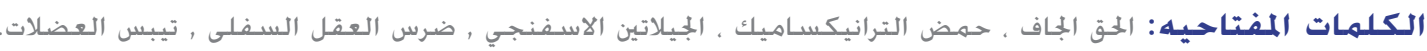

